\title{
360 Derece Performans Değerlendirme Sistemi ve Özel Bir Sağlık Kuruluşu Uygulama Örneği
}

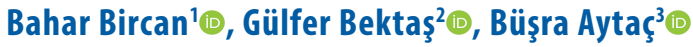

'Acıbadem Sağlık Grubu Genel Müdürlüğü, İ̧ Geliştirme ve Proje Müdürü, İstanbul, Türkiye

${ }^{2}$ Acıbadem Mehmet Ali Aydınlar Üniversitesi, Sağlık Bilimleri Fakültesi, Sağlık Yönetimi Bölümü, İstanbul, Türkiye

${ }^{3}$ Marmara Üniversitesi, Sağlık Bilimleri Enstitüsü, Sağlık Yönetimi Yüksek Lisans Programı, İstanbul, Türkiye

Bahar Bircan, Sağlık Yön. Uzm Gülfer Bektaş, Doç. Dr. Büşra Aytaç, Yüksek Lisans Öğrencisi

Illetişim:

Doç. Dr. Gülfer Bektaş

Acıbadem Mehmet Ali Aydınlar Üniversitesi, Sağlık Bilimleri Fakültesi, Sağılk Yönetimi Bölümü, İstanbul, Türkiye Tel: +902165004192

E-Posta: gulfer.bektas@acibadem.edu.tr
ÖZET

İşletmelerin insan kaynakları yönetimi fonksiyonlarından biri olan performans değerlendirmede etkinliğin ve verimliliğin ölçülebilmesi son derece önemlidir. Küreselleşmenin etkisi ile değişen ve gelişen koşullara uyum sağlamak durumunda kalan işletmeler için performans değerlendirme çalışmalarının önemi artmış, hem kamu hem de özel sektörde çeşitli yöntemlerle uygulanmaya başlamıştır. Özellikle son on yılda performans değerlendirme süreçlerinin ve yöntemlerinin hızlı bir ilerleme kaydettiği görülmektedir. Örgütler ise yaşanan bu değişimlere ayak uydurabilmek için, işgörenlerin; kendileri ve üstlerinin yanı sıra diğer çalışma arkadaşları ve bazı durumlarda hizmet veya ürün sundukları müşterileri tarafından da değerlendirilmesini sağlayan 360 derece performans değerlendirme sistemini tercih etmeye başlamışlardır.

Bu çalışmada amaçlanan, 360 derece performans değerlendirme yönteminin sistem içerisindeki etkisine yer vermekle beraber, diğer hastane çalışanları için uygulanabilirliği konusunda zemin oluşturmaktır. Ayrıca, Türkiye genelinde hizmet sunan özel bir sağlık kuruluşunun 360 derece performans değerlendirme sistemi detaylı şekilde incelenmiş, değerlendirme detayları ve sonuçları paylaşılmıştır.

Anahtar sözcükler: İnsan kaynakları, insan kaynakları yönetimi, performans değerlendirme, 360 derece performans değerlendirme sistemi

\section{DEGREE PERFORMANCE EVALUATION SYSTEMS AND ITS APPLICATION IN THE CASE STUDY OF A PRIVATE HEALTH-CARE PROVIDERABSTRACT}

It is of crucial importance to measure efficiency and productivity in performance evaluation, one of the human resource management functions of enterprises/businesses. With the impact of globalisation and the rapidly changing and evolving scape of enterprises/businesses, performance evaluation methods have increasingly become more prominent tools for enterprises/businesses, particularly in the last decade, and have been applied in various forms and methods in both public and private sectors. In order to keep up with these changes, organizations have started to employ comprehensive, 360-degree performance evaluation systems that allow organisations to be evaluated by their superiors, colleagues as well as by their customers.

The aim of this study is to provide an analysis of how such comprehensive, 360-degree performance evaluation methods can be applied in enterprises/businesses, particularly in the health-care sector and on health-care workers. The study also critically examines and evaluates the 360-degree performance evaluation system employed by a private health-care provider as a case study.

Keywords: Human resources, human resources management, performance assessment, 360-degree performance assessment method
Gönderilme Tarihi : 20 Şubat 2019

Revizyon Tarihi : 20 Mayıs 2019

Kabul Tarihi : : 24 Mayıs 2019 
Y aşadığımız 21. yüzyıl sürekli bir değişim süreci içindedir. Aynı zamanda hızla yaşanan küreselleşme nedeni ile örgütlerin rekabet avantajı elde edebilmek için değişen yönetim şekillerini takip etmeleri, gerekirse de yeni yönetim modelleri uygulayıp geliştirebilmeleri gerekmektedir. İş görenlerin ve yöneticilerin, kişisel ve mesleki gelişimlerini göz önünde bulunduran performans değerlendirme sistemlerini uygulaması, işletmenin hızlı değişimlere uyum sağlamasını kolaylaştıracaktır. Performans değerlendirme modellerinden biri olan 360 derece performans değerlendirme sistemi, insan kaynakları yönetim sürecinin önemli bir parçasıdır (1). Uygulama sürecinde yönetimle beraber çalışanlar ve organizasyonun kendisi de büyük rol oynamaktadır. Böylece sistem ile birlikte hem çalışanlar hem de yöneticiler karar süreçlerinde söz sahibi olur ve çok yönlü bir değerlendirme sağlanmış olur (2). Bu nedenle sistemin kullanımının önemi artmakta, buna paralel olarak kullanım gerekçeleri de oldukça çeşitlilik göstermektedir. Strateji oluşturmak, düzene uyum sağlamak, motivasyonu ve performansı arttırmak ve performans sonuçlarını değerlendirmek bu gerekçeler arasında yer almaktadır (3). Giderek popüler hale gelmekte olan 360 derece değerleme sistemi daha çok personelin gelişimi amacıyla kullanılmaktadır (4).

\section{Performans değerlendirme süreci}

Başarılı bir performans değerlendirme süreci yapılabilmesi için, başta insan kaynakları birimi olmak üzere tüm yöneticilerin ve değerlendiricilerin, aşağıda yer alan evreleri eksiksiz ve özenle yürütmeleri son derece önemlidir. Bu evreler seçilen performans değerlendirme yöntemine ve yaklaşıma göre değişiklik göstermekle beraber tüm performans değerlendirme sistemleri için ortak niteliktedir.

Performans değerlendirmesinde ilk evre, işgörenlerin iş alanlarının tanımlanmasıdır. Tanımlama yapııırken örgütün başarısı için işgörenin bireysel performansının gerekli olan boyutları belirlenmelidir. Bu boyutlar, değerlendirme kriteri, değerlendirme faktörü veya yetkinlik olarak da adlandırılabilmektedir. Teknik bilgi ve beceri, ekip çalışmasına yatkınlık, kuruma bağlılık örnek olarak verilebilir. Performans değerlendirmenin ikinci evresi, işgörenlerin performanslarının ne düzeyde yeterli ya da yetersiz olduğunun ölçülmesidir. Ölçüm yapııırken bazı ölçeklerden yararlanılabilir. Bu ölçekler içerisinde, beklentinin çok altında, gelişmesi gerekli, başarılı, çok başarılı, üstün başarılı gibi sınıflandırmalar yer alabilir. Üçüncü evre ise sürecin en önemli ve kritik evresidir. Bu evrede performans değerlendirmenin sonuçlarına ilişkin bilgi iş görenle paylaşılır. Bu paylaşım esnasında önceki dönemlere ilişkin değerlendirme ve sonuçlar, ilerideki performansın gelişmesini sağlamak üzere kişiye aktarılır.

\section{0 derece performans değerlendirme} sistemi

Performans değerlendirme modellerinden biri olan 360 derece performans değerlendirme sistemi, insan kaynakları yönetim sürecinin önemli bir parçasıdır. Bu sistemin temel amacı, performans değerlendirmesinden ziyade, kişiye farklı kaynaklar tarafından geribildirim verilmesini olanaklı kılarak, kişisel gelişimini sağlamaktır (1). 360 Derece Performans Değerlendirme Sistemi, performans değerlendirme metodolojisi içinde çok yönlü ve sürekli bir anlayışla sorgulamayı amaçlayan, amirlerin ve yöneticilerin yanı sıra, değerlendirilenin kendisinin (öz değerlendirme), iş arkadaşlarının (yandaşlarının), astlarının ve iş kolunda mevcut ise müşterilerin de değerlendirme yaptığı bir sistemdir ve performans hakkında geribildirim sağlar $(5,6)$. Örgütün güçlü ve zayıf yönlerinin belirlenmesi, işgörenlerin eğitim, motivasyon ve performanslarında artış sağlanması, iletişim düzeyinin gelişmesi ve çok yönlü bir geri bildirim mekanizmasının oluşması bu sistemin sağladığı avantajlar arasında yer almaktadır.

360 derece geri bildirim uygulamalarına genel olarak bakıldığında örgütlerin örgütsel farklılıklarını, kendi yapı ve gerçeklerini dikkate alarak değerlendirme ölçeklerini hazırlaması ve alt kriterlerini belirlemesi gerekmektedir $(7,8,9)$. Bu ölçeklerin ve alt kriterlerin doğru bir şekilde belirlenmemesi, yapılan değerlendirmenin amacına ulaşmasını engelleyecektir. Performans değerlendirmesinde bir diğer kritik konu ise, yapılacak değerlendirmenin amacının açık ve doğru bir şekilde katılımcılar ile paylaşılmasıdır. Amacın doğru ve eksiksiz bir şekilde ifade edilmemesi durumunda, katılımın yeterli sayıya ulaşması mümkün olamayacaktır. 360 derece performans değerlendirme sisteminde hata yapılması, sonuçların yanlış veya eksik çıkmasına, dolayısı ile de

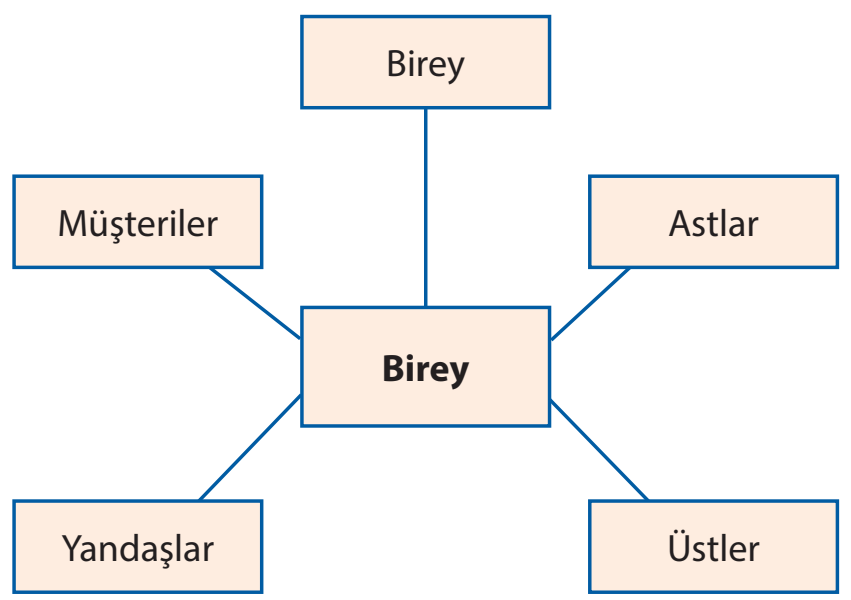

Şekil 1: 360 Derece performans değerlendirme sistemi 


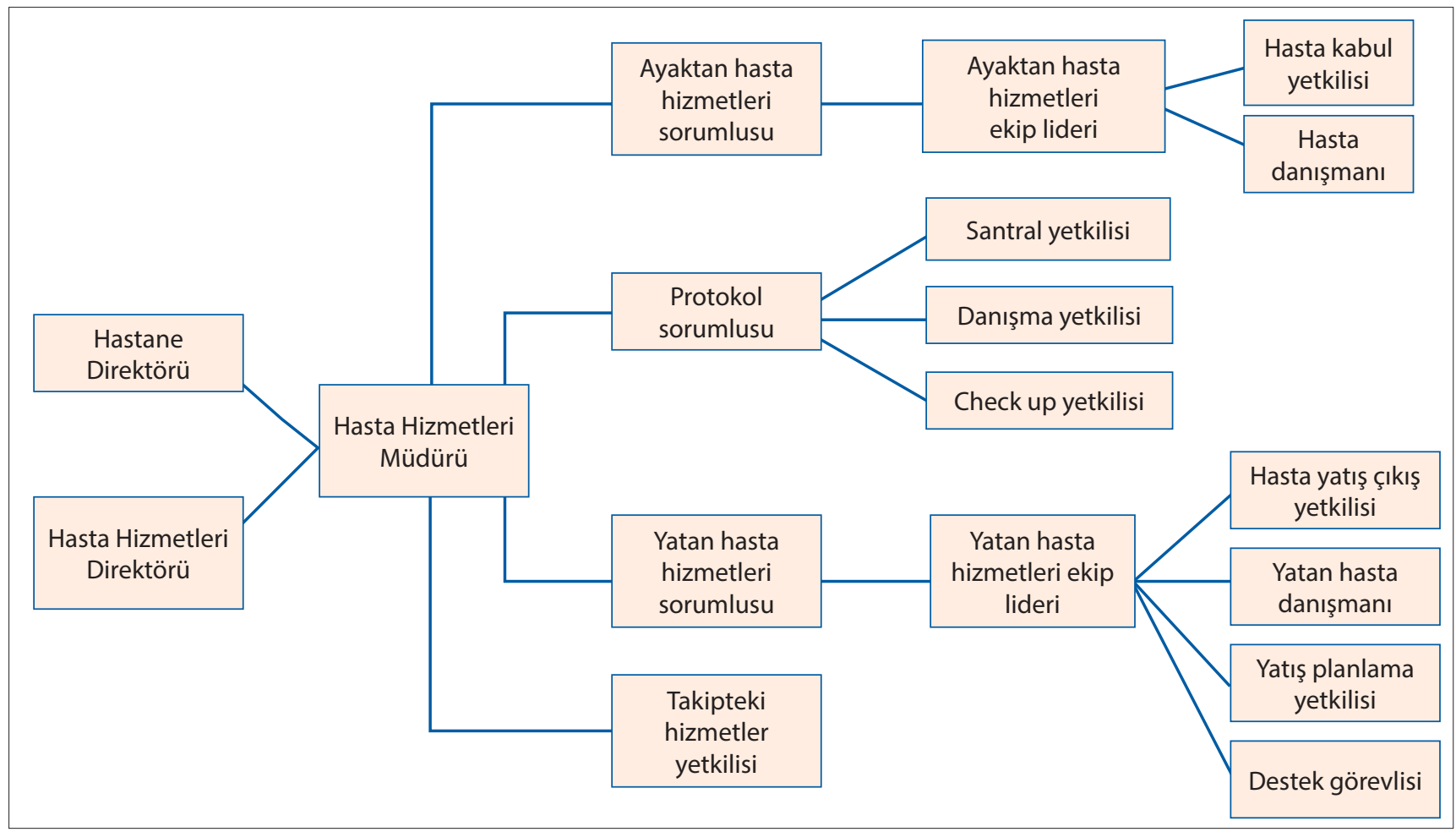

Şekil 2: Hasta hizmetleri organizasyon şeması

sisteme ait güvenilirliğin kaybolmasına neden olacaktır. Bu sebeple sistemin eksiksiz ve güvenilir olarak uygulanması için; değerlendirme sonuçlarının gizli tutulması, geri bildirimin bir uzman tarafından işgörenlere açıklanması, sayısal veri ve yazılı raporlar ile sürecin açıklanması, geri bildirim sonrası işgörenlerin gelişimlerinin takip edilmesi gibi dikkat edilmesi gereken bazı unsurlar bulunmaktadır $(3,10,11)$.

\section{0 derece performans değerlendirme sistemi ve özel bir sağlık kuruluşu uygulama örneği}

Bu bölümde Türkiye genelinde hizmet sunan özel bir sağlık kuruluşunun 2015 yılından itibaren, şu an sadece hasta hizmetleri yönetici grubu için uyguladığı, insan kaynakları uygulamalarından birisi olan 360 derece performans değerlendirme uygulama örneği incelenmiştir. 360 derece performans değerlendirme örneğinin detayları aktarılmadan önce "Hasta Hizmetleri" tanımı ve yönetici görev tanımlarına yer verilmiştir.

Hasta Hizmetleri, hasta ve yakınlarının karşılanması, randevu verilmesi, kayıt ve ödeme işlemleri, hastaneye yatış süreçleri, taburculuk işlemleri, gerektiğinde eşlik edilip yönlendirilmesi gibi tüm idari süreçlerde hizmet veren kişilerden oluşan, oldukça kalabalık bir gruptur.
Ayaktan / Yatan Hasta Hizmetleri Ekip Lideri: Kendisine bağlı olan ekibin her türlü ihtiyacını yerine getiren (teknik bilgi intiyacı, izin talebi, eğitim analizi ve takibi, iptal-iade fatura süreci, tüm tedarik süreci vs.) ve ekibinin yaptığı tüm işleri denetleyen, ekibinin motivasyonunu yüksek tutarak en üst düzeyde performans göstermelerini sağlayan tecrübeli yöneticidir.

Ayaktan/Yatan Hasta Hizmetleri Sorumlusu: Ekip liderinin yürüttüğü süreçleri takip ve kontrol eden, ekibin performansını izleyen ve değerlendiren, gelişimlerine destek olan, gerektiğinde olumlu veya olumsuz geri bildirimler veren tecrübeli yöneticidir.

Protokol Sorumlusu: Sürekli ve yüksek kalitede protokol hizmeti sunulmasını desteklemek üzere yerli, yabancı, Premium, ViP hasta ve yakınlarına ihtiyaç duydukları sağlık hizmeti için yardımcı olan tecrübeli yöneticidir.

Hasta Hizmetleri Müdürü: Politika prosedür ve standartların oluşturulmasına öncülük eden ve bu doğrultuda hasta hizmetleri planlaması yaparak performansın yönetimini sağlayan tecrübeli yöneticidir.

Hastane Direktör Yardımcısı: Kurumun misyon, vizyon ve stratejileri doğrultusunda operasyonel ve finansal 
hedefleri oluşturan ve bu hedeflere ulaşmak için gerekli koordinasyonu ve hastane işletmeciliğinin profesyonel şekilde icra edilmesini sağlayan tecrübeli yöneticidir.

Hastane Direktörü: Kurumun misyon, vizyon ve stratejileri doğrultusunda yönetim sorumluluğunu üstlendiği hastanenin hedeflerini oluşturan, operasyonel ve finansal planların yapılmasını, bütçe ve iş planları doğrultusunda hastane faaliyetlerinin ve kaynak kullanımının yönetilmesini, tüm bölümlerin standartlara, yürürlükteki yasa ve yönetmeliklere uygun şekilde çalışmasını sağlayan yöneticidir.

Sağlık grubunda Hasta Hizmetleri için organizasyon şeması şekil 2'de gösterilmektedir. Unvanlar ve birimler şubenin yapısına göre değişiklik gösterebilmektedir.

\section{0 derece performans değerlendirme amacı}

Modelin, anketlerin değerlendirilmesi ve analiz edilmesi sonrasında ekip lideri ve sorumlu grubunun eğitim ihtiyacının belirlenmesi ve gelişime açık alanlarının iyileştirilmesi için fırsat sunması hedeflenmektedir. Aynı zamanda kişisel farkındalığı arttırmak, takım çalışması ve iletişimi güçlendirmek, kurum aidiyetini, güvenini, çalışan motivasyonunu ve verimliğini arttırmak da bu uygulamanın amaçları arasındadır.

\section{0 derece performans değerlendirme yöntemleri}

İlgili sağlık kuruluşunda, 360 derece performans değerlendirme sistemine karşılık gelen "Yönetsel Yetkinlik Anketi" uygulaması yapılmaktadır. Uygulamaya ilk defa 2015 yılında başlanmış ve uygulandığı ilk yıl sadece "Ayaktan/Yatan Hasta Hizmetleri Ekip Lideri" unvanındaki yöneticiler değerlendirilmiştir. Grup genelinde 12 şubedeki 115 ekip lideri için 1.290 adet anket doldurulması planlanmış, bu anketlerin \%90'ı tamamlanmıştır. 2016 yılında değerlendirme sürecinde bir değişiklik yapılması düşünüldüğünden yönetsel yetkinlik anketi uygulanmamıştır. 2017 yılında ise değerlendirilen grubuna "Ayaktan/Yatan Hasta Hizmetleri Sorumlusu", "Protokol Sorumlusu" ve "Fatura Kontrol Sorumlusu" unvanındaki yöneticiler dâhil edilmiş, ayrıca ekip lideri ve sorumluların yandaş (eş görevdeki) ekip arkadaşları da değerlendirici olarak sisteme eklenmiştir. İlgili yılda; 16 şubedeki 138 ekip lideri ve 71 sorumlu için 2.476 adet anket doldurulması planlanmış, bu anketlerin \%86'si tamamlanmıştır.

Tablo 1'de bu uygulama süreci özetlenmiş olup, organizasyon şemasında yer alan aşağıdaki unvanlar "Hasta Hizmetleri Yetkilisi" başlığında toplanmıştır.

Bu modelde hangi yöneticinin kim tarafından değerlendirileceğini hasta hizmetleri müdürü belirlemektedir. Modelden yola çıkarak, bir ekip liderinin değerlendirilmesinde; ekip liderine bağlı olan ekibi, yandaş ekip liderleri, hasta hizmetleri sorumlusu, hasta hizmetleri müdürü, direktör/direktör yardımcısı, liderin kendisi yer almaktadır. Bu durumda bir ekip lideri için sistemde en az 6 adet anket doldurulması gerekmektedir. Ekip üyeleri tarafından ekip liderinin değerlendirilmesi için her bir ekip üyesine, yandaş ekip liderinin bir ekip liderini değerlendirmesi için de her bir ekip liderine ayrı ayrı anket ataması yapılmaktadır. Dolayısı ile her bir ekip lideri için ekip sayısına ve ekip

Tablo 1. Yönetsel yetkinlik anketi değerlendirici/değerlendiren tablosu

\begin{tabular}{lcr} 
Derğerlendirici & Değerlendirdiği Yönetici & Ek Bilgi \\
\hline Hasta Hizmetleri Ekip Lideri & Kendi Sorumlusu+Yandaş Ekip Liderleri & $\begin{array}{c}\text { Hasta Hizmetleri Ekip Lideri } \\
\text { Aynı zamanda kendisinide değerlendirir. }\end{array}$ \\
\hline Hasta Hizmetleri Sorumlusu & Kendi Ekip Lideri+Yandaş Sorumlular & $\begin{array}{c}\text { Hasta Hizmetleri Sorumlusu } \\
\text { Aynı zamanda kendisinide değerlendirir. }\end{array}$ \\
\hline Protokol Sorumlusu & Kendi Ekip Lideri+Yandaş Sorumlular & $\begin{array}{c}\text { Protokol Sorumlusu } \\
\text { Aynı zamanda kendisinide değerlendirir. }\end{array}$ \\
\hline Fatura Kontrol Sorumlusu & & Fatura Kontrol Sorumlusu \\
\hline Protokol Sorumlusuna Bağlı Tüm Ekip & Protokol Sorumlusu & Aynı zamanda kendisinide değerlendirir. \\
\hline Fatura Kontrol Yetkilisi & Fatura Kontrol Sorumlusu & Sadece Protokol Sorumlusunu değerlendirir. \\
\hline Hasta Hizmetleri Yetkilisi & Kendi Ekip Lideri+Kendi Sorumlusu & Sadece Fatura Kontrol Sorumlusunu değerlendirir. \\
\hline Hasta Hizmetleri Müdürü & Tüm Ekip Liderleri+Tüm Sorumlular & Tüm Ekip Liderleri ve Sorumluları değerlendirir. \\
\hline Direktör/Direktör Yard. (isteğe Bağlı) & Tüm Ekip Liderleri+Tüm Sorumlular & Tüm Ekip Liderleri ve Sorumluları değerlendirir. (İsteğe Bağlı)
\end{tabular}


lideri sayısına bağlı olarak anket atanması ve doldurulması gerekmektedir. Örneğin 2017 yılında toplam ekip lideri ve sorumlu sayısı 209 iken, 2.129 adet anket doldurulmuştur.

Sorular Hasta Hizmetleri Direktörlüğü ve İnsan Kaynakları Direktörlüğü'nden oluşan bir ekip tarafından belirlenmiştir. Bu aşamada doğru kişiye doğru soruların sorulması 360 derece performans değerlendirme sürecindeki önemli adımlardan biri olduğundan soruların netleştirilmesi için uzun süren çalışmalar yapılmıştır. Aşağıda yer alan Tablo 2 ' de ayaktan/yatan hasta hizmetleri sorumlusunu değerlendiren tüm değerlendiricilerin (tarafların) yanıtlaması istenen anketlere ait sorular verilmiştir.

Hazırlanan anket soruları 5’li Likert ölçeği mantığı ile yanıtlanmakta olup, puanlaması aşağıdaki şekilde olmaktadır.

- Kesinlikle Katılmıyorum (0 puan)

- Katılmıyorum (2,5 puan)

- Kısmen Katılıyorum (5 puan)

- Katılıyorum (7,5 puan)

- Kesinlikle Katılıyorum (10 puan)

Anketin sonunda değerlendiricinin görüşlerini açıcça yazabilmesi için iki adet açık uçlu soru bulunmaktadır. Bu açık uçlu sorular aşağıdaki şekilde ankette yer almaktadır.

- Ekip Liderinizi/Sorumlunuzu birkaç cümle ile nasıl tanımlarsınız?

- Varsa Ekip Liderinizden/Sorumlunuzdan beklentileriniz nelerdir?

Uygulamaya başlamadan önce, hasta hizmetleri direktörlüğü ekipleri tarafından SurveyMonkey sitesinden anketler ve değerlendirici isimleri sisteme tanımlanmaktadır. Anketin uygulamaya açılma tarihinde hasta hizmetleri direktörlüğü tarafından, anketi değerlendirmesi istenen şubelere unvan bazında bir e-posta gönderilmektedir. Yönetsel yetkinlik anketi SurveyMonkey sisteminde ortalama iki ay süre ile açık kalmaktadır. Bu süre boyunca hasta hizmetleri direktörlüğü sistemi sürekli takip ve kontrol etmek sureti ile şube müdürlerine anket doldurulma sayıları ve oranları ile ilgili raporlar göndermektedir. Doğru ve anlamlı bir sonuca ulaşabilmek için anket doldurma oranının her bir değerlendirilen yönetici için $\% 85$ ve üzeri olması hedeflenmektedir. Anket doldurma hedefine ulaşıldıktan sonra elde edilen verilerin ortalaması Excel formatı ile alınır. Yapılan hesaplamalar sonucunda, soru ve sorumlu bazında puanlama tabloları oluşturulmaktadır. Uygulanan model içerisinde yer alan iki açık uçlu sorunun
Tablo 2. Hasta hizmetleri sorumlusu için sorulan anket soruları

\section{Soru Değerlendirilen Unvan/Sorumlu}

Değerlendirici Unvan/Ekip +Ekip Lideri

1 intiyacım olduğumda sorumluma kolaylıkla ulaşabilirim

2 intiyacım olduğumda sorumlum bana yeterli zaman ayırabilmektedir.

3 Sorumlum sorunlarımı kısa bir sürede çözebilmektedir

4 Sorumlum tutum ve davranışları ile bize örnektir

5 Sorumlumun beni bir birey olarak önemsediğini hissediyorum.

6 Sorumlum bir konuyu açıklarken; her zaman sabırlı ve detaylı bir şekilde anlatır.

7 Sorumlum mesleki gelişimimi izler ve destekler

8 Sorumlum yaptı̆ı̆ işi takdir eder ve teşvik ederek cesaretlendirir.

9 Sorumlum beni çalışma arkadaşlarımın yanında eleştirmekten kaçınır.

10 Sorumlunuzu birkaç cümle ile nasıl tanımlarsınız?

11 Varsa sorumlunuzdan beklentileriniz nelerdir?

\section{Soru Değerlendirilen Unvan/Sorumlu}

\section{Değerlendirici Unvan/Kendisi (Sorumlu)}

1 intiyaç duyduğunda, ekibiniz size kolaylıkla ulaşabilir.

2 intiyaç duyduğunda, ekibinize yeterli zaman ayırabilirsiniz.

3 Ekibinizin sorunlarını kısa bir sürede çözebilirsiniz.

4 Tutum ve davranışlarınız ile ekibinize örnek bir ekip liderisiniz.

5 Ekibinizdeki herkesi bir birey olaral önemsersiniz.

6 Bir konuyu açıklarken; ekibinize her zaman sabırlı ve detaylı bir şekilde anlatırsinız.

7 Ekibinizin mesleki gelişimini izler ve desteklersiniz.

8 Ekibinizin yaptığı işi takdir eder ve teşvik ederek cesaretlendirirsiniz.

9 Ekibinizi çalışma arkadaşlarının yanında eleştirmekten kaçınırsınız.

10 Kendinizi bir sorumlu olarak birkaç cümle ile nasıl tanımlarsınız?

11 Sizce ekibinizin sizden beklentileri neler olabilir?

Soru Değerlendirilen Unvan/Sorumlu

Değerlendirici Unvan/Hasta Hizmetleri Müdürü

1 Sorumlum ekip içerisinde adil bir yönetim tarzı sergilemektedir. (izin, vardiya planı, böbet vb.)

2 Sorumlum ekibi ile ilişkilerini etkin bir şekilde yönetir.

3 Sorumlumun mesleki ve teknik bilgisi yeterli düzeydedir.

4 Sorumlum ekibinin yönetiminde gerekli motivasyonu sağlayabilir.

5 Sorumlum hedeflere ulaşılması için ekibine gerekli yönlendirmeyi ve desteği sağlar.

6 Sorumlum ekibine geribildirim vermek konusunda başarlıdır.

7 Sorumlum kendi eğitimi ve ekibinin eğitimi ile yakından ilgilenir.

8 Sorumlum çalışanların yetkinliğini izler, performans verilerini takip eder.

9 Sorumlum önceliklerini belirleme, planlama ve problem çözme becerisine sahiptir.

10 Sorumlum ekibiyle gerçekleştirdiği toplantıları etkin ve düzenli bir şekilde gerçekleştirir.

11 Sorumlunuzu birkaç cümle ile nasıl tanımlarsınız?

12 Varsa sorumlunuzdan beklentileriniz nelerdir?

\section{Soru Değerlendirilen Unvan/Sorumlu} Değerlendirici Unvan/Yandaş (Sorumlu)

1 Ekibi intiyaç duyduğunda, ona kolaylıkla ulaşabilir.

2 Ekibi intiyaç duyduğunda, omlara yeterli zaman ayırabilir.

3 Ekibinin sorunlarını kısa bir sürede çözebilir.

4 Tutum ve davranışları ile ekibine örnek bir ekip lideridir.

5 Ekibindeki herkesi bir birey olarak önemser.

6 Bir konuyu açıklarken; ekibine her zaman sabırlı ve detaylı bir şekilde anlatır.

7 Ekibinin mesleki gelişimini izler ve destekler.

8 Ekibinin yaptığı işi takdir eder ve teşvik ederek cesaretlendirir.

9 Ekibini çalışma arkadaşlarının yanında eleştirmekten kaçınır.

10 Çalışma arkadaşlarınızı birkaç cümle ile nasıı tanımlarsınız?

11 Varsa çalışma arkadaşınızdan beklentileriniz nelerdir? 
değerlendirilmesi ise şube yöneticileri tarafından yapılmakta ve değerlendirilen yöneticiye verilen puanların ortalamalarının yazıldığı özet tablo sayesinde yöneticiler arasında yetkinlik kıyaslaması yapmak mümkün olmaktadır. Bu rapor sayesinde geri bildirime ve eğitime ihtiyacı olan yöneticilerin belirlenmesi sağlanmaktadır.

\section{Bulgular}

Tablo 3 ve 4, anket takibi ile ilgili hasta hizmetleri direktörlüğünden şube müdürüne iletilen raporun örneğini göstermektedir. Tablo 3'e göre, sorumlular detayında 277 anket atanmış ancak bunların 99'u tamamlanmıştır (\%36). Sorumlular arasında atanan anket sayısı ve tamamlanma oranlarına bakıldığında 13 sorumludan 9'unun tamamlanma oranları \%50'nin altında kalmaktadır. 9.sorumluya bakıldığında anketlerin tamamlanma oranı \%100 iken kendisine daha az anket atanmış 6. ve 13.sorumluların anket tamamlanma oranları \%0'dır. Unvanlar bazında anket tamamlanma oranlarına bakıldığında (Tablo 4) ise en çok anket atamalarının ekip üyelerine yapıldığı (278) ancak en az tamamlanma oranı (\%36) ile geri dönüş alındığı, dağıtılan anketler arasında en çok tamamlanma oranına (\%94) ise ekip liderlerinin ulaştığı görülmektedir.

Anketlerin analizi sonrasında, değerlendirilen yöneticinin kendisini çok iyi bir durumda konumlandırdığı fakat ekipten aldığı puanların bunun aksi olduğu görülebilmektedir. Bunun bir örneği Tablo 5'de 1.sorumlu verilerinde görülebilir. 1.sorumlu kendisine en yüksek puanı $(10,00)$ vermiş ancak eş görevdeki arkadaşları tarafından düşük bir puan $(4,44)$ almıştır. Aynı zamanda ekibi ve ekip lideri tarafından yapılan değerlendirmede de puanlarının yüksek olduğu $(8,68 ; 9,65)$, eş görevdeki çalışma arkadaşlarından sonra en düşük puanlamanın müdürü tarafından $(7,25)$ yapıldığı görülmektedir. Bu puanlama tablosunun değerlendirilmesi sonucunda; sorumlunun kendisi ve ekibi tarafından objektif değerlendirilemediği ya da eş görevdeki arkadaşları ile arasında bir çekişme olduğu söylenebilir. Bu sorumlu hakkında doğru bir değerlendirme yapılabilmesi için, açık uçlu soruların cevaplarının dikkatlice değerlendirilmesi, eş görevdeki çalışma arkadaşları ile olan ilişkilerinin yakın takip edilmesi ve müdürü tarafından daha fazla geri bildirimle desteklenmesi gerektiği sonucu çıkarılabilir.

Bu duruma bir diğer örnek olarak 12.sorumlu verilebilir. Sorumlular içinde ekibinden $(3,73)$ ve müdüründen $(3,00)$ en düşük puan alan sorumlunun 12.sorumlu olduğu görülmektedir. Ekip liderlerinin yaptığı puanlamada $(3,89)$ da oldukça düşük bir puan almıştır. Buna rağmen 12. sorumlu kendisine en yüksek puanı $(10,00)$ vermiştir. Diğer taraftan
Tablo 3. Sorumlu detayinda anket doldurulma tablosu

\begin{tabular}{lccc}
$\begin{array}{l}\text { Sorumlu Adı } \\
\text { Soyadı }\end{array}$ & $\begin{array}{c}\text { Atanan Anket } \\
\text { Sayıs }\end{array}$ & $\begin{array}{c}\text { Doldurulan Anket } \\
\text { Sayıs }\end{array}$ & $\begin{array}{c}\text { Tamamlanma } \\
\text { Oranı }\end{array}$ \\
\hline 1. Sorumlu & 12 & 2 & $17 \%$ \\
2. Sorumlu & 15 & 2 & $13 \%$ \\
3. Sorumlu & 28 & 1 & $4 \%$ \\
4. Sorumlu & 45 & 18 & $40 \%$ \\
5. Sorumlu & 35 & 26 & $74 \%$ \\
6. Sorumlu & 11 & 0 & $0 \%$ \\
7. Sorumlu & 12 & 9 & $75 \%$ \\
8. Sorumlu & 18 & 4 & $22 \%$ \\
9. Sorumlu & 15 & 15 & $100 \%$ \\
10. Sorumlu & 54 & 13 & $24 \%$ \\
11. Sorumlu & 9 & 1 & $11 \%$ \\
12. Sorumlu & 15 & 8 & $53 \%$ \\
13. Sorumlu & 8 & 0 & $0 \%$ \\
Toplam & 277 & 99 & $36 \%$
\end{tabular}

Tablo 4. Tüm unvanlar detayında anket doldurulma tablosu

\begin{tabular}{lccc} 
Unvan & $\begin{array}{c}\text { Atanan Anket } \\
\text { Sayısı }\end{array}$ & $\begin{array}{c}\text { Doldurulan Anket } \\
\text { Sayısı }\end{array}$ & $\begin{array}{c}\text { Tamamlanma } \\
\text { Oranı }\end{array}$ \\
\hline Ekip & 278 & 99 & $36 \%$ \\
Ekip Lideri & 18 & 17 & $94 \%$ \\
Sorumlu & 13 & 5 & $38 \%$ \\
Sorumlu Yandaşı & 68 & 41 & $60 \%$ \\
Müdür & 13 & 11 & $85 \%$
\end{tabular}

Tablo 5. Sorumlular için özet puan tablosu

\begin{tabular}{lccccc}
\multicolumn{5}{c}{ Değerlendirici } \\
\hline Değerlendirilen & Ekip & Ekip Lideri & Müdür & Kendi & Yandaşı \\
\hline 1. Sorumlu & 8,68 & 9,65 & 7,25 & 10,00 & 4,44 \\
2. Sorumlu & 7,56 & 4,51 & 7,00 & 7,22 & 5,23 \\
3. Sorumlu & 9,51 & & & 9,44 & 6,39 \\
4. Sorumlu & 7,67 & 5,93 & 7,50 & 8,89 & 6,50 \\
5. Sorumlu & 6,94 & 7,90 & 8,00 & 8,89 & 7,28 \\
6. Sorumlu & 9,23 & 7,78 & 8,75 & 9,72 & 7,11 \\
7. Sorumlu & 9,62 & 9,17 & 7,25 & 10,00 & 6,67 \\
8. Sorumlu & 5,74 & 4,91 & 5,75 & 8,89 & 3,47 \\
9. Sorumlu & 7,52 & 8,75 & 6,75 & 8,33 & 6,22 \\
10. Sorumlu & 7,13 & 8,37 & 9,25 & 9,17 & 7,39 \\
11. Sorumlu & 6,81 & & & & \\
12. Sorumlu & 3,73 & 3,89 & 3,00 & 10,00 & 7,22 \\
13. Sorumlu & 6,76 & 2,96 & 4,75 & 9,72 & 6,39 \\
Ortalama & $\mathbf{5 , 7 4}$ & $\mathbf{5 , 5 6}$ & $\mathbf{6 , 2 5}$ & $\mathbf{8 , 3 3}$ & $\mathbf{5 , 6 7}$
\end{tabular}


da yandaş sorumlular tarafından oldukça yüksek $(7,22)$ bir puanlamaya tabi tutulmuştur. Sorumlu, ekibi, liderleri ve müdürü tarafından olumsuz değerlendirilmiş, fakat eş görevdeki sorumlu grubunca olumlu görüş belirtilmiştir. Bu değerlendirme sonucunda üst yöneticisinin değerlendirilen yöneticiyi yeterince takip etmemiş olması, zamanında geri bildirim vermemesi, ekibi ile yeterli iletişimin sağlanmaması, değerlendirilen yöneticinin hata yapmasına ve kendini farklı konumda görmesine yol açabilmektedir. Bu yöneticilerin ekipleri ile olan ilişkileri iyi değerlendirilmeli ve yakın takip edilmelidir. Belli aralıklar ile geri bildirim görüşmeleri organize edilmeli, olumsuz sonuçları yaşamadan önce kişilere gereken fırsatlar tanınmalı ve gelişimleri desteklenmelidir.

Elde edilen bulgulara göre, tüm değerlendiriciler tarafından benzer puanlamalar alan sorumluların (6. ve 10. sorumlular) işini hakkıyla yaptıkları ve çevresiyle sağlıklı bir iletişim halinde oldukları, başarılarının ödüllendirilerek performanslarının daha da arttırılabileceği söylenebilir. Aynı şekilde kendisi dışında tüm değerlendiriciler tarafından düşük puanlar alan sorumluların (8. ve 13.sorumlular) performanslarını iyileştirici çalışmalar yapılması gerektiği de söylenebilir. Sorumlular bazında değerlendiricilerin ortalama puanları karşılaştırıldığında ise her değerlendirici grubu dâhil olmak üzere en yüksek puanlamanın kişinin kendisine yapıldığı $(8,33)$, en düşük puanlamanın ise sırasıyla 5,56; 5,67; 5,74 puanlarıyla ekip lideri, yandaş ve ekip üyeleri tarafından yapıldığı görülmektedir. Değerlendiricilerin birbirlerini düşük puanlamalarının sebeplerini daha iyi anlayabilmek için açık uçlu sorulara verilen cevaplar dikkatlice incelenmiş, en büyük sebebin

\section{Kaynaklar}

1. Aytaç A. 360 Derece Performans Değerlendirme. Bilim ve Aklın Aydınlığında Eğitim Dergisi 2003;4;41.

2. London M, Beatty R. 360-Degree Feedback As A Competitive Advantages. Human Research Management 1993;32;353-72. [CrossRef]

3. Lepsinger R, Lucia A. D. Creating Champions for 360 Degree Feedback. Training \& Development Magazines 1998;49-52.

4. Dessler G. Human Resource Management. Sydney: Prentice Hall PTR, 1999: 156.

5. Canıtez A B, Solmuş T. Performans Değerlendirmesi. Türk Psikoloji Bülteni 2000; 16-7.

6. Camgöz M, Alperten IN. 360 Derece Performans Değerlendirme ve Geri Bildirim: Bir Üniversite Mediko-Sosyal Merkezi Birim Amirlerinin Yönetsel Yetkinliklerinin Değerlendirilmesi Üzerine Pilot Uygulama Örneği. Celal Bayar Üniversitesi İktisadi Ve İdari Bilimler Fakültesi Yönetim Ve Ekonomi Dergisi 2006:13:191-210. gruplaşmanın ve rekabet olduğu ortaya çıkmıştır. Bu çaIışmayla beraber, çalışanlar arasındaki rekabetin olumsuz etkilerini azaltmanın ve iletişimi güçlendirmenin hem performansı arttıracağı hem de daha yansız bir performans ölçümü yapılabileceği söylenebilir.

\section{Sonuç}

Performans değerlendirmesinde daha doğru veriler elde edilmesi için hem kişinin kendisi tarafından hem de birlikte çalıştığı kişiler tarafından değerlendirilmesi son derece önemlidir. Anket analizleri incelendiğinde çalışanlar arasındaki yakınlığın, çatışmanın, rekabetin ve iletişimin puanlamalara yansıdığı ve performans ölçümünü etkilediği görülmüştür. Dolayısıyla 360 derece performans sistemi uygulaması sadece kişinin performansını ölçmekle kalmayıp, farklı değerlendiriciler tarafından kişinin puanlanmasını ve puanlama esnasında kişinin değerlendiricilerle arasındaki iletişimin de incelenmesini sağlamaktadır. Böylece tüm yönetici ve sorumlular çalıştıkları ekipleri daha iyi analiz edebilir ve buna göre önlemler alabilir. Değerlendirme sonucunda kişilerde eksik görülen yeterliliklerin iyileştirilmesinin yanında kişiler arasındaki iletişimin geliştirilmesi ve gruplaşmaların önlenmesi için de kurumsal iyileştirilmeler yapılabilir. Bu bağlamda, değerlendirme sonuçlarının kişilerin gelişimi ve ilerlemesi için bir fırsat olarak kendisine sunulduğu ve tüm sonuçların kişinin kariyer planlamasında göz önünde bulundurulduğu görülmektedir. 360 derece performans değerlendirme sisteminin her yıl düzenli olarak uygulanması ve sonuçların yıllara göre karşılaştııılarak iyileştirme sonuçlarının değerlendirilmesi sağlıklı bir performans ölçümü için önemli olacaktır.

7. Illleez AA, Güner M. Personel Performans Değerlendirme Ve 360 Derece Performans Değerlendirme Yöntemi. Ege Üniversitesi Tekstil Ve Konfeksiyon Araştırma Uygulama Merkezi Dergisi 2006;17:325.

8. Kaynak R, Bülbül M. 360 Derece Geri Bildirim Sisteminde Değerlendirme Farklııkları. Süleyman Demirel Üniversitesi İktisadi Ve İdari Bilimler Fakültesi 2008;13:271

9. Uyargil C. İşletmelerde Performans Yönetimi Sistemi. İstanbul. Arıkan Basım Yayım Dağıtım 2008:102-111.

10. Vinson MN. The Pros And Cons Of 360-Degree Feedback: Making it Work", Training And Development Magazines 1996; 50:11-2.

11. Wimer S. The Dark Side Of 360-Degree Feedback. Training \& Development Management 2002;56:37-42. 